

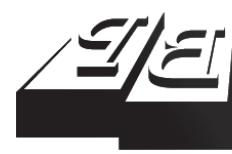

\section{BUSINESS PERSPECTIVES}

(O)

LLC "CPC "Business Perspectives" Hryhorii Skovoroda lane, 10, Sumy, 40022, Ukraine www.businessperspectives.org
Received on: $2^{\text {nd }}$ of May, 2021 Accepted on: $10^{\text {th }}$ of June, 2021 Published on: $17^{\text {th }}$ of June, 2021

(c) Viktoriia Koilo, 2021

Viktoriia Koilo, Ph.D., Associate Professor, Department of Ocean Operations and Civil Engineering, Faculty of Engineering, Norwegian University of Science and Technology, Norway.

\title{
DEVELOPING NEW BUSINESS MODELS: LOGIC OF NETWORK VALUE OR CROSS-INDUSTRY APPROACH
}

\begin{abstract}
Digital transition in the maritime industry creates new organizational models and af fects the relationship between actors. New relationships require new business models (BMs). In addition, due to the paradigm of green shifts towards a zero-emission future of maritime shipping in 2050, stricter regulations require new solutions, and "business as usual" is not actual anymore. Thus, the study aims to investigate key drivers for creating new BMs and factors for their effective implementation by companies. The results of the study point to the main reasons for creating BMs. It was revealed that there are several external and internal prerequisites. Moreover, it was proved that considering the current tendency of the interfaces in relationships with different industries, it is important to talk about the development of BMs not only from a supply chain perspective. Moreover, it should be considered from the point of view of network value. Hence, the study highlights the need for a further investigation that aims to design new solutions, implement, test, and observe the effect of new BMs, considering collaborative ties between interested parties.
\end{abstract}

\section{Keywords}

JEL Classification

\section{INTRODUCTION}

In the era of uncertainties and global changes, the only way to survive is to be updated, flexible to changes, creative, and always willing to take risks. Presently, global market conditions are not reliable and environmentally friendly, many factors force all companies to rethink their strategies, business models (BMs), and ways of doing businesses in general. No industry could avoid the impact of the pandemic situation that occurred in 2020. New reality gives new lessons, one way to handle the situation is to learn from the past and be open for new solutions: "there's always an opportunity with a crisis. Just as it forces an individual to look inside himself, it forces a company to reexamine its policies and practices" (Smith, n.d.).

The Norwegian and international economy has been through several crises and recessions over the past 15 years and has undergone restructuring. Together with major fluctuations in international trade policy and a change in global trade flows, this has resulted in less predictable markets for the whole maritime industry.

Since the winter of 2020 and the eruption of COVID-19, the maritime industry has been hit by one of the biggest economic crises in modern times. The crisis has had dramatic consequences for activities, jobs, 
and financial ability at a time when the industry was previously financially vulnerable as a result of an ongoing restructuring following the fall in oil prices from 2014.

The ability of the maritime industry to adapt to new requirements for emission reduction, new digital technology, and new markets will affect its competitiveness in the years ahead. At the same time, the industry must have future-oriented and predictable framework conditions that provide an opportunity to adapt to developments. In this perspective, emphasis is placed on the development of new knowledge, competence, technology, and new BMs.

Public support and innovative policy are very important. To facilitate restructuring and innovation in the Norwegian maritime industry, the government should pursue a maritime policy that provides good general framework conditions for maritime activities, with particular emphasis on promoting the development of climate- and environmentally-friendly shipping, digitalization of the maritime sector, and Norwegian maritime competence.

In addition to external factors, there are internal ones that prove the importance of looking for new BMs, as existing ties are already changing in the industry. A good example of it could be evidenced from the Norwegian Blue Maritime cluster (BMC), which is famous for its complicity by having all actor and full supply chain on the West coast of Norway. Currently, many companies have already started to look for new opportunities and new BMs. Jakobsen et al. (2020a) stated "the traditionally tightly integrated value chain, once the key feature of the Blue Maritime cluster, is becoming "looser" and the cluster linkages are weakened. As many of the shipping companies have not ordered ships for years, the yards have been forced to find new customers and new relationships".

The maritime industry is in the midst of a paradigm shift, where regulations such as the IMO and the EU's taxonomy force the industry to become more sustainable with alternative energy sources. Meanwhile, considering sustainable development, apart from the environmental dimension, there are also economic and social aspects that should be considered, especially when it comes to the effectiveness of new technology.

Therefore, it is important to look at business models and check if old one are actual today and which new BMs can be better and more efficient, if necessary. Hence, the current study is quite relevant. Firstly, it is important to shed the light on the concept of $\mathrm{BM}$ and the main aspects of its creation.

\section{THEORETICAL BACKGROUND}

In conditions of competition and strategic development of the companies, new BMs become the most important element of the adaptive management system.

The concept of a "business model" is inextricably linked with the problem of inter-firm interactions, since the value is created jointly by numerous companies interacting in the market. Even though many researchers consider the $\mathrm{BM}$ as a separate unit of analysis, the question of its unified theoretical foundation is still open. This paper summarizes the areas of studies of BMs, defines the concep- tual foundations of this concept, its structure, and links with the company strategy, and highlights key ways of developing BMs.

\subsection{The concept of a business model}

The concept of a "business model" of an organization is currently one of the least unambiguous and structured terms in modern scientific literature. There is a comprehensive overview of approaches to the definition of this concept.

Rappa (2006) noted that in the simplest definition, a BM is a way of implementing a business, which provides an enterprise with income and profit. The BM formally reflects the process of making 
money, defines in detail its disposition and role in the value chain.

According to Timmers (1998), a BM consists of a set of products, services, and information flows, as well as descriptions of various participants in the business process, their role in the value chain, and potential social benefits with deciphering the sources of income. To understand the company business mission, a marketing model is added that combines BMs and marketing strategies of the desired business representative.

Osterwalder and Pignet (2010) noted that the BM interprets how an enterprise creates, delivers, and captures the value. In this case, the BM is a blueprint for how the company strategy should be implemented within its internal structures, processes, and systems. Business performance is based on three important life cycles: product, consumer demand, and a BM. If the turning points of these cycles are not identified in time and the phases are not managed, there is a huge loss of value.

Gorgijn et al. (2000) added several important additions to the definition of the term "business model". It was stated that the term "business model" is often misunderstood and confused with the term "business process model". A BM describes the processes of exchange of value, value between various participants in the business process, i.e. $\mathrm{BM}$ represents the foundation for implementation of business processes (Figure 1).
According to Stähler (2002) and Magretta (2002), a $\mathrm{BM}$ is a conceptual description that explains how an enterprise operates. The BM explains how business units fit together and integrate into a single structure. The $\mathrm{BM}$ is not considered in isolation from the strategy, but it is not identical to it. Unlike strategy, a BM does not focus on performance and efficiency criteria.

This is called the third approach. First, it emphasizes the distinctive features inherent in the company strategy and its BM. For example, the strategy is considered to focus on competition and competitive advantage, while the $\mathrm{BM}$ is considered to focus on cooperation, partnership, and co-creation of value.

BM describes how company activities interact to implement a strategy. In this case, BM is based on fragmentary and incomplete information, and the strategy is based on the completeness and reliability of information (Amit \& Zott, 2008).

It is argued that $\mathrm{BM}$ is an independent intermediate component located between the company strategy and its business processes (Solaimani \& Bouwman, 2012).

It should be noted that developing the concept of a BM and emphasizing its strategic orientation, Hamel (2000) identified four components of a BM: core strategy, strategic resources of the company, customer profile, and value chain.

Source: Compiled by the author.

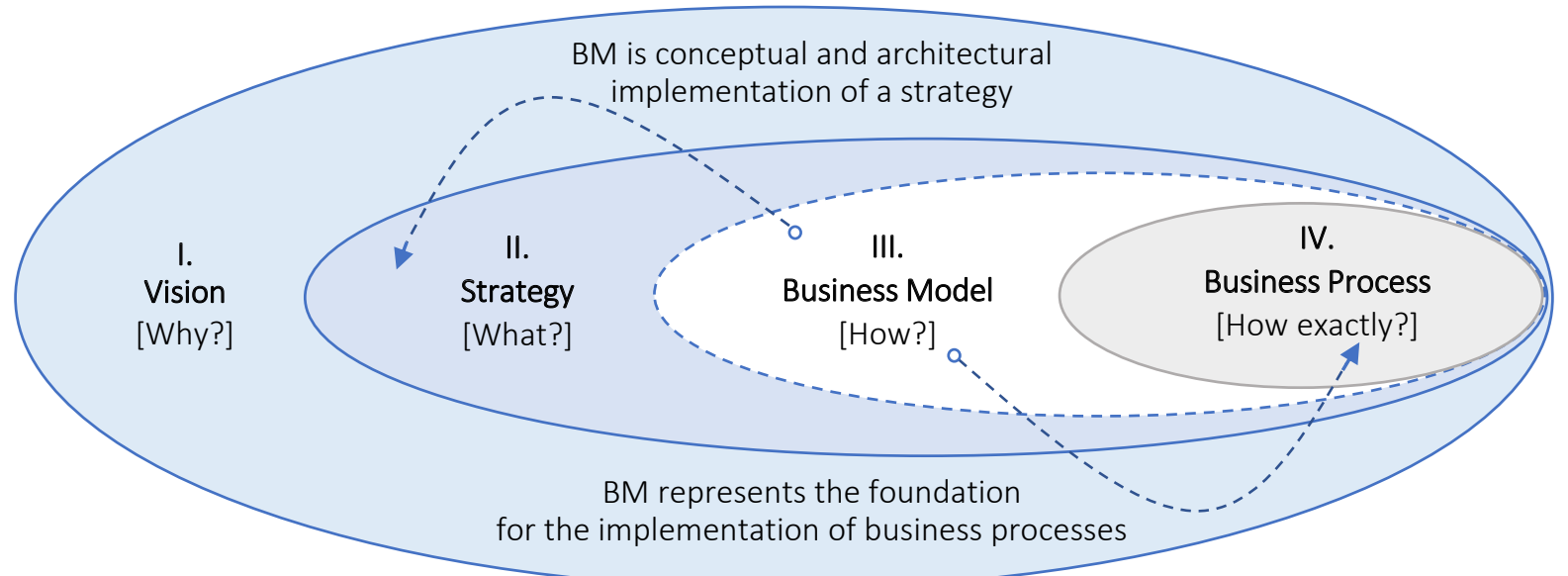

Figure 1. Relationship between business model, business process, company strategy, and company vision 
BM typically includes the following main components: value proposition, market segment, value chain structure, cost and profit structure, position within the value chain, and competitive strategy. Very often same approach of understanding a BM can be found under the term "Business Model Canvas".

Business Model Canvas is a template for describing how a company or project/product creates value and makes money on it. It is also known as the Osterwalder matrix. Canvas is a visual representation of current or emerging BMs commonly used by strategic managers. It provides a unified view of business as a whole and is especially useful for benchmarking the impact of increased investment on any of the contributing factors. Typically, a BM is either a generic model common in the industry or a random combination of systems and processes, created in the blink of an eye to achieve the main goal - to sell a product or service. It is needed so that the output is a working result.

Successful start-ups do not enter the market with their first idea. Instead, the product/service usually goes through several iterations before arriving at the final version. Likewise, organizations will be more resilient if they consider several BMs before choosing a specific one.
There are four main aspects of a business that is possible to find in Business Model Canvas (Osterwalder \& Pigneur, 2010): customer, offer, infrastructure, and finance.

The business model triangle is a good representation of how value is created, delivered, and captured (Figure 2):

1. Value creation (value proposition): how a company helps customers to solve a problem or perform the job they want to be done.

2. Value delivery (resources, activities, and partners): what resources, activities, and partners are needed for the company to carry out the value promise.

3. Value capture (profitability logic): how a company makes money using a given income model and cost structure.

In addition, Business Model Canvas classifies the processes and internal activities of a business into nine distinct categories, each of which is a building block in the creation of a product or service. All nine categories are listed and disclosed in Table 1.

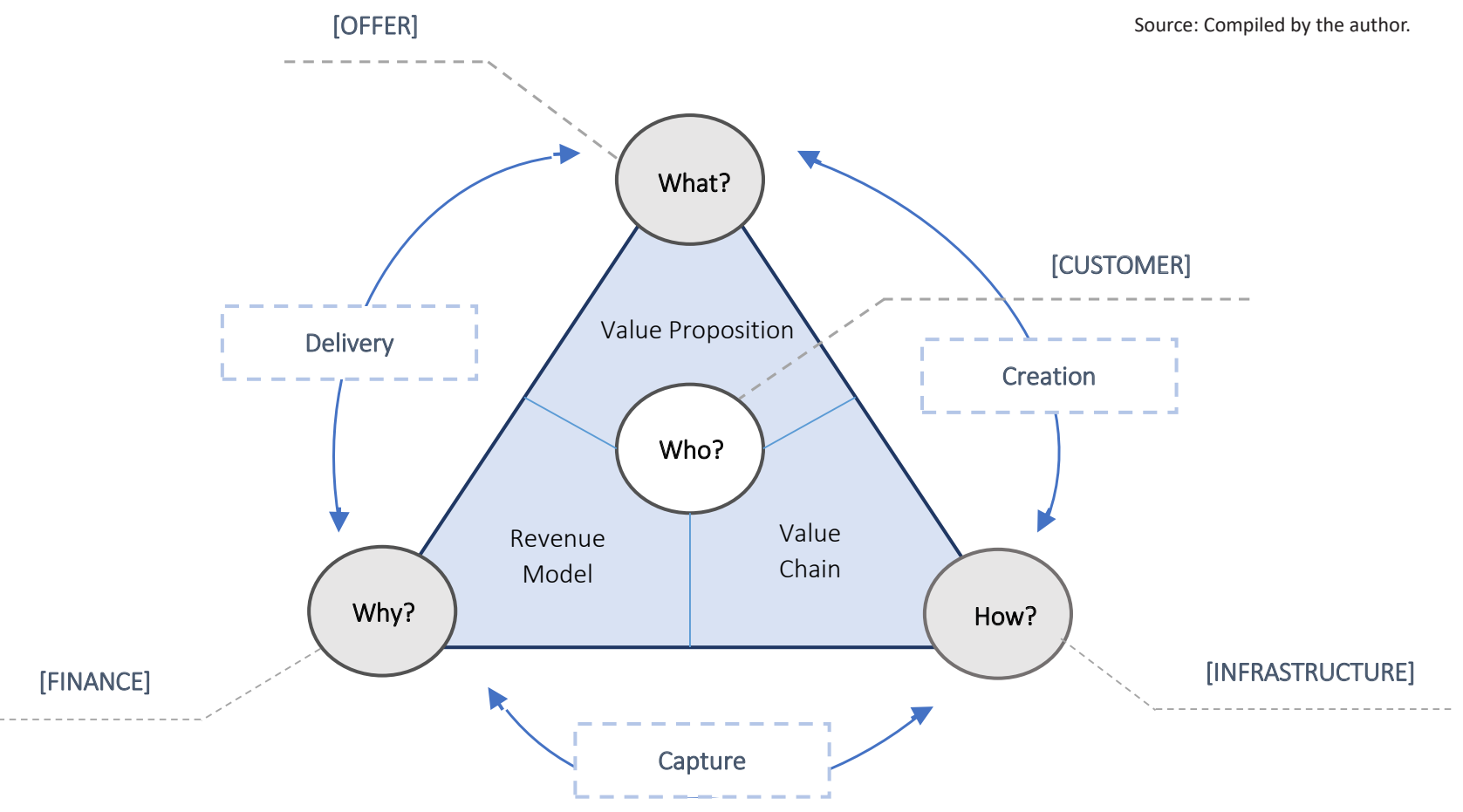

Figure 2. Business model triangle 
Table 1. Key structural elements of Business Model Canvas

\begin{tabular}{|c|c|}
\hline Structural elements & Explanation \\
\hline Key activities (KA) & What are the key actions to take? Production? Software? Supplies? \\
\hline Key resources (KR) & What key resources do we need? Financial, physical, human \\
\hline Key partners (KP) & $\begin{array}{l}\text { Who are your key partners? Who are your key suppliers? What do we get from them? What do } \\
\text { we provide them? }\end{array}$ \\
\hline Customer relationships (CR) & How do we acquire, retain, and "grow" customers? \\
\hline Target customers (TG) & $\begin{array}{l}\text { Who are our most important customers? What segments can they be divided into? What do } \\
\text { they want us to do for them? }\end{array}$ \\
\hline Channels $(\mathrm{CH})$ & Through which channels do our clients want us to communicate with them? \\
\hline Revenue streams (RS) & List your sources of revenue and work models \\
\hline Cost structure (CS) & $\begin{array}{l}\text { List your fixed and variable costs such as development costs, customer acquisition costs, } \\
\text { hosting, etc. }\end{array}$ \\
\hline Value proposition (VP) & $\begin{array}{l}\text { What problems do we solve for our customers? What needs do we satisfy? Key product } \\
\text { benefits for the customer that help solve a problem or satisfy a need? }\end{array}$ \\
\hline
\end{tabular}

It should be noted that the list of BM components is becoming more and more homogeneous; typically, it includes the participants in the interaction who create value for the customer, the types of these interactions, and their results.

All prerequisites for developing a new $\mathrm{BM}$ are already mentioned. Due to those changes, structural elements have already been shifted in existing industrial models. Hence, there can be found several $\mathrm{BM}$ archetypes that are popular in economic literature.

Sustainable business model. Presently all industries facing new challenges are linked to the requirements of sustainable development. Moreover, there is a fundamental shift in the purpose of business, and rethinking perceptions of value. In other words - the way of doing business has been already influenced by the UN 2030 Agenda. Thus, there is a need to find new BMs that are based on gaining competitive advantage, while resolving social and environmental issues (Dentchev et al., 2018). In the literature review, they are often called sustainable business models (SBMs).

Business model innovation. In addition, in economic literature, there can be found another type of BM that is emerging by applying the innovation system approach - business model innovation (BMI). This type of model is recognized as a key to the creation of sustainable business (Laukkanen \& Patala, 2014). There are different barriers in transition to this type of model based on innovations. To facilitate company and system-level sustainability there is a need for structural and cultural changes. According to Jacob (2004), this type of BM is directed on embed- ding new technologies and new digital solutions into existing industrial models. The main important idea of BMI is that it is not always about making changes in the product or the production process, but in the way it is brought to the market.

Sustainable business model innovation. A combination of the above-mentioned approaches is defined as sustainable business model innovation (SBMI): this BM archetype is based on a careful redesign of existing models. It is sustainability integration for mainstream and new start-ups - designing sustainable business from the outset (Stubbs \& Cocklin, 2008; Porter \& Kramer, 2011), and "business model innovations can support a systematic, on-going creation of business cases for sustainability" (Schaltegger et al., 2012). The most complete understanding of SBMI is described by Bocken et al. (2014). It is defined as "innovations that create significant positive and/or significantly reduced negative impacts for the environment and/or society, through changes in the way the organization and its value-network create, deliver value and capture value (i.e. create economic value) or change their value propositions" (Bocken et al., 2014). This type of model in modern literature is often called "eco-innovation business model". BM that linked to each type of eco-innovation has a different degree of changes in the structural elements of the model. Most shifts take place in activities connected to research and development (R\&D). Another change is connected to shifts in the relationships with new partners and new customers (OECD, 2012).

There are technology innovations enabling business models. The concept of BM innovation can refer to: 
1) establishing of a new and innovative $B M$ that creates a new market or changes the competition in the existing market;

2) current business is changing due to the present $\mathrm{BM}$ in a way that it has the same result.

\subsection{Development of a business model}

\subsubsection{Restart - 7 ways to sustainable business}

The model "Restart -7 ways to sustainable business" provides a roadmap in seven parts on how to give a company such a restart. Following are the tools to design sustainable business models that make money on new technologies, digitization, and the circular economy.

Restart - 7 ways to sustainable business includes following parts (Jørgensen \& Pedersen, 2017):

1) Rebranding: change how the company creates, delivers, and captures value in a way that it sheds the light and less shadow on society and the environment while promoting their competitiveness.

2) Experimentation: to succeed with business model innovation, companies must perform controlled experiments with the models and uncover what works and why.

3) Circularity: go from a linear business model based on "extract, use, throw away" to circular based on reuse, resource efficiency, sharing, and closed value chains. This can reduce resource depletion and waste as well as reduce costs and provide new sources of income.

4) Service logic: access rather than ownership - it involves sharing services, power services, and leasing-like payment models. It results in better capacity utilization and less resource waste (the seven wastes of lean manufacturing).

5) Alliances: to solve the sustainability problem, complex competence, technology, input factors, and other resources are often required. This may require alliances across industries. Open business models to others and collabo- rate so that the whole is more than the sum of its parts.

6) Result: prioritize measures that solve the significant issues (not just what looks good). Requires communication with stakeholders so that they are convinced that the company has effective measures. In addition, materiality analysis and the relationship between sustainability and profitability are relevant here.

7) Three-dimensionality: set the right goals financially, socially, and environmentally, measure and follow up, communicate to those who need the information. Reward the people and units that make it easier to be more sustainable. In addition, at this stage, it is important to have a bridge-builder to the surroundings: contact with stakeholders inside and outside the organization.

Restart (“4R" approach) should be conducted in 4 phases: (1R) Recognize - understand the current business model: how the company creates, delivers, and captures value, the company light and shadow casting and identifies the need for change; (2R) Rethink - identify opportunities and threats (technological and societal trends as well as competitors) and explore opportunities and barriers for an improved business model; (3R) Reinvent develop new ideas and hypotheses about what customers want, test them and decide on a new business model; (4R) Reorganize your business model - implement the new business model.

\subsubsection{Customer-oriented $B M$ creation}

Another aspect is the need for a "customer-oriented model" (Trimi \& Berbegal-Mirabent, 2012). It has been argued that "companies do not necessarily know the value preferences of their customers" (Pynnönen et al., 2012) so they must recognize customers as valuable actors who can play different roles in the BMI process. In addition, it is considered that the customer is the "starting point" of BMI, and is placed at the top of the BM. Visualization of all potential points of interaction with the client helps to determine how the client is involved in the definition of some parameters of BMs and affects others (Zolnowski et al., 2014). Chew (2016) proposed to first imagine what a unique client experience should 
be, and then, starting from this, start designing BMs and providing services. In turn, a four-stage system of business processes is proposed to analyze the correspondence between the current $\mathrm{BM}$ of the company and its value for the client (Pynnönen et al., 2012). Each of the elements of the BM is assessed under the value preferences of customers to determine the main and secondary components of the model and exclude elements that have no value (Pynnönen et al., 2012). Trimi and Berbegal-Mirabent (2012) emphasized how important it is to get client approval before starting to create BMs. In doing so, there is the idea of studying the client. The basic tenet of the customer research process is that a new approach or idea must be approved by customers for use in subsequent processes, otherwise, it will be sent back for revision. For BMI, customer approval includes validation of elements of BMs such as subjective value proposition, or appropriateness of prices or distribution channels. Finally, Pynnönen et al. (2012) emphasized the importance of continuous customer involvement in the BMI process to continuously and iteratively align the company BMs with current and emerging market needs and to receive real-time critical information about all changes in customer preferences.

\subsubsection{Co-creation of business models}

Co-creation of BMs encourages the active participation of supply chain partners in the creation of new models. In addition, an innovation paradigm is described that includes collaboration based on a common platform (Trimi \& Berbegal-Mirabent, 2012). Accordingly, co-innovation involves the creation of unique value and experience with external stakeholders. Analysis of the literature has shown that the transition to an open BMI process for the joint creation of BMs opens up new business opportunities and improves the quality of the developed models (Berre, 2013). It has been argued that the use of external communications and collaboration with partners to exchange information about the company BMs allows testing the commercial viability of a new model before it is put into practice (Chew, 2016). In particular, the literature highlights the role of customers and suppliers as valuable participants in the BMI process. Ogilvie (2015) argued that direct interaction with customers and potential partners helps to jointly search for solutions that bring profit to all stakeholders.
Ebel et al. (2016) emphasized that the involvement of a target group is critical to the success of BMI. Looking at co-creation from a client perspective, Ogilvie (2015) stated that clients are enthusiastic about being invited to co-create BMs and are enthusiastic about the idea of collaboratively finding new solutions.

In addition, it has been argued that "innovation in service and innovation in business model drives business growth" (Chew, 2016). For practical interaction, companies are encouraged to create an internal culture of "open leadership" and "organizational learning". Through operational experimentation with BMs, companies can test the commercial viability of new models before investing in their design and implementation (Chew, 2016). Ebel (2016) emphasizes certain flexibility in terms of resources and capabilities of BMs to ensure that they can be adapted to a changing market.

Chesbrough (2007) proposed a business model framework (BMF) that helps companies "to assess where their current BM stands in relation to its potential and then define appropriate next steps for the further advancement of that model". In addition, it was highlighted that very often BM remains unchallengeable: "it takes more time than that to develop business-model experiments, obtain clear results, interpret and understand the results, and then carry out a broad deployment of those results".

Indeed, many companies often are stopping at a stage of planning and testing new BM, as far as it requires long-term investment and the results can be achieved not in a short-term perspective. Another problem is that companies no longer can do it alone, as far as value is no longer created by firms acting autonomously, but by its collaborative process, so the creation of $\mathrm{BM}$ should be also considered from a supply chain perspective.

Hence, the literature review proves that there are many different types of BMs, approaches in creating them. Nevertheless, in practice, many companies still prefer to do "business as usual". Thus, the study aims to prove the need to create a new BM, i.e., to investigate the main drivers and reveal key factors for effective implementation of new BM by companies. 


\section{RESULTS}

\subsection{External prerequisites for creating a new business model}

\subsubsection{Global economic crisis and market changes}

One of the biggest challenges for many oil-oriented countries, including Norway, is the prospect of a deterioration in the trade balance as a result of a fall in oil and gas (O\&G) production in 2014, global coronavirus pandemic shocks in 2020, and increasing growth of competition on the global market.

Therefore, in the future exports from other industries will be increased. For example, among the counties ${ }^{1}$, Møre og Romsdal has a strong element of many basic industries. Within marine food, maritime transport, and leisure, Møre og Romsdal is the county with the highest number of person-years among counties. Moreover, this region has the highest export intensity in 2019: exports per employee in Møre og Romsdal were about NOK 1 million, followed by Vestland and Nordland, both just under NOK 600,000 (Jakobsen et al., 2020b).

Nevertheless, during last year due to the COVID-19 crisis, other exports also faced challenges throughout 2020, including a significant fall in fish prices. Some of this was offset by a fall in the Norwegian kroner in relation to the US dollar and euro, in which much of exports are settled. Presently the whole world experiences these consequences, but some countries, including Scandinavian, could perform better in export revenues: the statistics show that Norway's share of international trade has fallen, and fell faster than neighboring countries. This has happened even though Norway has significantly lower exports as a share of the GDP than both Sweden, the Netherlands, and Denmark. One of the reasons for lost market shares for Norwegian exporters is that the Norwegian wage and cost level is high. Compared with other European countries, the wage level increased significantly in Norway in the years following the financial crisis. In addition, Norwegian exporters have increasingly faced competition from new players in low-cost countries: in Asia (China, Korea, Japan, and Singapore), but also in the Western countries with a high share of exports such as Germany, Denmark, England, and the Netherlands. It should be highlighted that many of those countries also have significantly better support schemes than Norway.

\subsubsection{Green restructuring and technological development}

When products are standardized and volumes increase, competitiveness weakens. Competitiveness is the strongest in markets characterized by technological development, new solutions, and often in the development of new segments and markets. The Norwegian maritime industry has repeatedly shown an exceptional ability to adapt to new markets in challenging situations.

Currently, there are several ambitions for a green future: offshore wind, batteries, production of hydrogen and ammonia, $\mathrm{CO}_{2}$ capture, reduction in carbon intensity, renewable energy and hydropower, and energy efficiency.

Offshore wind. Currently, this segment represents a great opportunity to further develop a renewable industry in Norway and it is a well-functioning domestic market that is important for the Norwegian supplier industry and the green jobs of the future. Furthermore, the more companies that can take part in the technology development, the more opportunities it provides for industrial exports.

Hydrogen. Norway recently joined a collaboration on hydrogen projects - Important Projects of Common European Interest (IPCEI), approved by the European Commission (2018). The benefits of using hydrogen in maritime transport are several. In ferry transport, for example, hydrogen will be able to solve several limitations seen in both charging and storing energy with electric ferries. If a battery ferry has to charge 40 times a day, there can be a lot to gain by storing some of the energy as hydrogen. Hydrogen is suitable for many types

1 Norwegian administrative region. Norway is divided into 11 administrative regions, called counties (Norwegian: fylke). 
of boats other than ferries, short sea shipping, aquaculture, fjord cruises, fishing, etc.

Batteries. About 100 offshore vessels have the potential to be rebuilt to combine the use of battery and diesel to reduce fuel consumption. Such a redevelopment program will support close to 2,000 person-years in the maritime cluster. Nowadays companies of the O\&G industry actively work towards systematical reducing their carbon intensity "by developing new types of vessels and using alternative fuels in close collaboration with the industry" (Equinor, 2020).

Automation. The development and use of digital technology in society have accelerated and provided gains, opportunities, and challenges. Digitization and automation are increasingly affecting the maritime industry through more automated processes onboard vessels and more integrated systems. This provides opportunities for optimization of operations and better communication and security. At the same time, it entails new requirements for competence, new security challenges related to information and digital vulnerability, and new BMs as well.

Carbon capture and storage (CCS). CCS is part of the governmental industrial and climate initiative, which, among other things, allocates funds to the demonstration project "Longship" for $\mathrm{CO}_{2}$ management. The ambition for the project is to realize a cost-effective solution for full-scale $\mathrm{CO}_{2}$ management in Norway. Key Norwegian players such as Norcem, Fortum, and Equinor are involved in the project.

To sum up, if Norway succeeds in a green restructuring of the maritime industry, Norwegian players have the potential to strengthen international market shares. According to Jakobsen and Helseth (2021), annual export earnings from the maritime industry (shipyards and equipment) can be doubled from 2019 to 2030, so that their total revenues increase from NOK 100 billion in 2019 to NOK 200 billion in 2030. Moreover, green jobs are needed to replace oil jobs. The number of oil employees may decrease by an average of 4,000 to 6,000 per year from 2025 to 2050, according to Regjeringen (2021). Since Møre og Romsdal's export companies rarely manage to compete on price in global mar- kets, their products must be high-quality innovative and eco-friendly. At the same time, there are significant costs associated with the green transition. This is also mentioned by companies of Møre as a potential threat.

Therefore, innovation and restructuring of the Norwegian maritime industry towards new markets are necessary to achieve continuous value creation and employment. In other words, another important condition for developing a new $\mathrm{BM}$ is efficient innovation policy as a key factor in creating a favorable environment for business development.

\subsubsection{Innovation policy}

Presently, it is quite common to talk about innovation policy that shows the importance of "positive structural changes" (Foray, 2009): there is a close relationship between industrial and innovation policy. These relationships aim to promote industrial diversification, which in turn will lead to economic growth, job creation, and competitive position in the market.

European Commission (2014) developed a cohesion policy 2014-2020 "National/regional innovation strategies for smart specialization (RIS3)", which means EU's growth strategy is directed to create a smart, sustainable and inclusive economy. It is highlighted that "countries and regions should diversify their economies primarily based on existing strengths and capabilities by moving into related and unrelated sectors". Hence, smart specialization (S3) is presented like a policy that should build on "each region strengths, competitive advantage and potential for excellence" (European Commission, 2014).

Grillitsch and Asheim (2018) considered "smart specialization" as a new type of industrial innovation policy. The main idea of the concept is that there should be two preconditions that will ensure the development of the right innovation policy. The first is system differentiation, and another one is industrial diversification. Thus, the Norwegian cluster Møre og Romsdal has all conditions for system differentiation (unique environment, tight connections within the cluster, high-speed incremental innovations capabilities, good collabora- 
tion with higher education governance support, etc.). Regardless of industrial diversification, there is still a low level of sharing the competencies between industries, where knowledge and resources from existing industries can be used in new ones, for example, renewables.

In fact, over the last 10 years, large shipyards have been responsible for advanced construction projects such as offshore vessels and expedition cruises; hence, the experiences from these projects are good to bring with them for the construction of vessels in other offshore segments that are likely to grow strongly in the future. The offshore wind wave is already underway, and based on the market outlook, many ships will have to be built in this segment over the next 10 years. Offshore mineral extraction is a less mature industry, but the potential is great, and the large shipyards in Møre og Romsdal should have good conditions for building ships for this industry. Finally, it is worth mentioning that vessels for $\mathrm{O} \& \mathrm{G}$ will be ordered again in the future (Jakobsen et al., 2020b).

To sum up, current innovation strategies for smart specialization that is becoming more popular far beyond the EU zone create the preconditions for a serious rethinking of current BMs, as long as it leads to building new relationships and sharing the competency within new market actors. Hence, the internal relationship within new supply chains is also one of the prerequisites for creating new BM.

\subsection{Internal prerequisites for creating a new business model}

According to Jakobsen et al. (2020b), the companies of BMC are connected through four different types of relationships:

- Vertical links - companies linked together through customer-supplier relationships, in other words through deliveries of goods and services. This is called value chains.

- Horizontal links - companies linked together through complementarity in the market (e.g., tourism, where different industries such as accommodation, catering, and culture together deliver a holistic experience product) or sub- stitutability in the market (i.e., the same scope for different products/services, e.g., different forms of knowledge).

- Knowledge and competence links - companies and knowledge actors linked together through common or complementary input factors, technologies, processes, and competence needs (e.g., power-intensive industry or technology industry).

- Ownership links - individual companies can be part of the same group or be controlled (e.g., through majority ownership) owner/owner grouping, which provides strategic opportunities, both in the form of making it easier to utilize synergies in value chains and horizontal links and by being able to allocate capital and resources between units.

Value creation is proved to be a process that can no longer be done autonomously; moreover, it is vitally important to involve other external parties through formal or informal agreements (Beattie \& Smith, 2013). In other words, new BMs should be viewed considering collaborative ties (Zott et al., 2011).

Zolnowski et al. (2014) stated the idea of "network value logic": to facilitate the integration of external partners and interaction with them, it is important to accept the "logic of network value" rather than focusing all attention on a separate value chain (Figure 3).

According to Amit and Zott (2001), there are four types of value creation sources:

1) increase in efficiency: occurs due to the reduction, primarily, of transaction costs, reduction of asymmetry of information, increase in the speed of transactions;

2) complementarity: interdependencies between products and services for customers (both vertically and horizontally), between online and offline business, between applied technologies and strategies of entrepreneurial activity;

3) "locking" customers: the level of competition between companies increases, and then strat- 


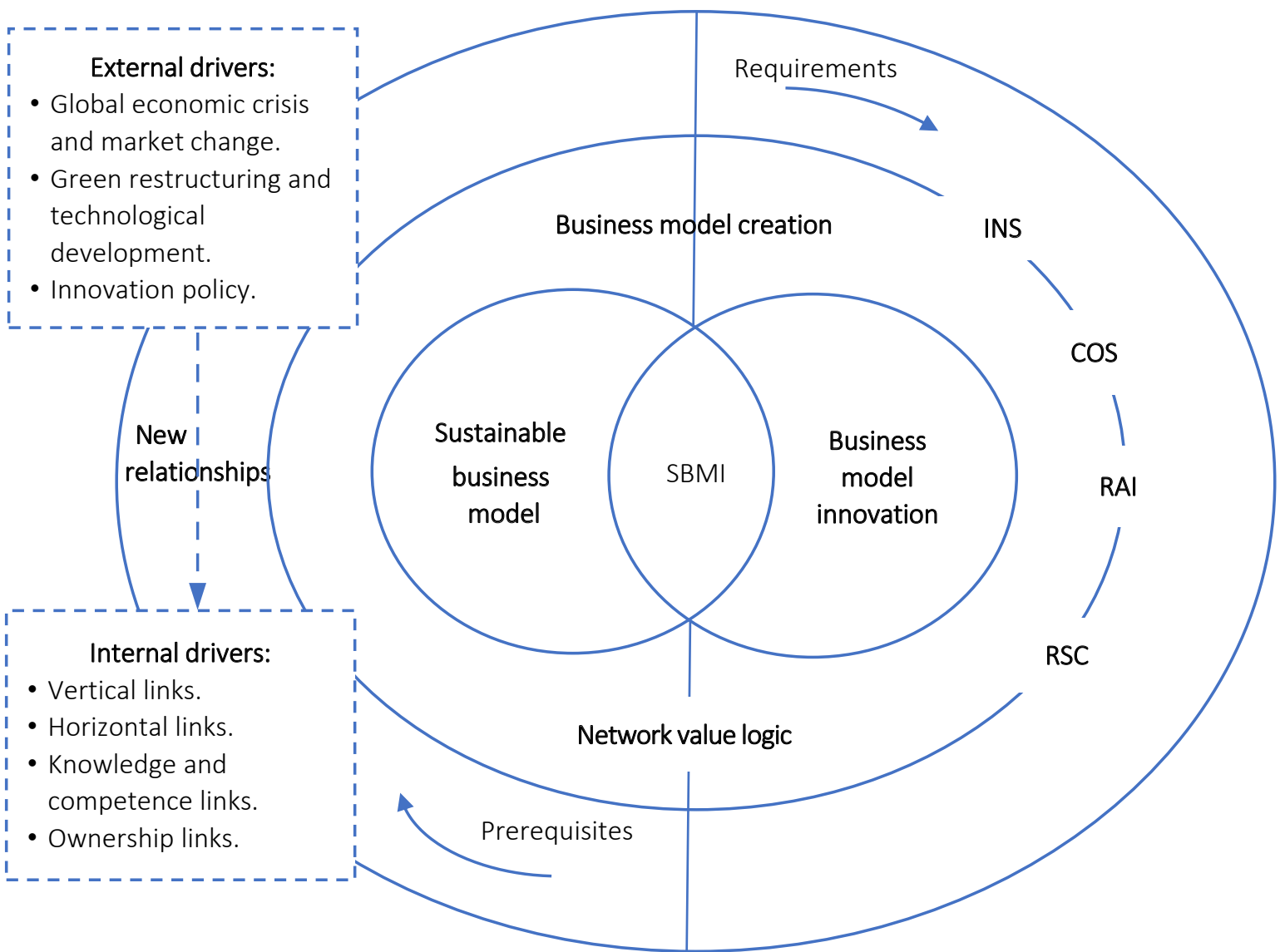

Note: $\mathrm{SMBI}$ - sustainable business model innovation; INS - innovativeness; COS - competency; RAI - reduction of asymmetry of information; RSC - relationship within the supply chain.

Figure 3. Theoretical framework: prerequisites and requirements for creating a business model (network value logic)

egies are needed for creating various loyalty programs for customers, deepening customization, creating "happiness" for the customer as a sale driver;

4) innovativeness: to achieve leadership, constant (daily) innovations are required (in the services provided, in content, etc.)

The presence of all four factors in the value chain will increase customer value and the potential for further market growth.

Indeed, the Norwegian export companies of BMC are known for delivering high-quality products and are technologically advanced. Nevertheless, no company is completely self-sufficient, and the most powerful compa- nies are found in dynamic business environments or ecosystems. Hence, the level of innovativeness is vitally important for value creation, but without reliable coordination, strong value chains relationship, and other links between companies and industries the efforts can be not enough efficient.

Thus, the development of BM is a process that requires innovativeness (INS), growing competency (COS), on the one hand, and reduction of asymmetry of information (RAI), strengthening the relationship within the whole supply chain (RSC), on the other hand.

Therefore, it is proved that there is a need to create new BMs, at the same time the process must be a joint interaction of external parties. 


\section{DISCUSSION}

It should be noted that when it comes to value creation especially in the Norwegian maritime industry, the number of companies is always larger as it often includes actors associated with other industries. An example is Kongsberg Maritime, which is an IT company, but which primarily delivers maritime activity (Helseth et al., 2021). The interfaces with the petroleum industry are particularly important, and there is an overlap between the supplier industry in the $O \& G$ and maritime industries (Figure 4).

Furthermore, the economic ties are quite high, e.g., the players related to maritime activities in $\mathrm{BMC}$ were behind $12 \%$ of the value creation generated in the petroleum industry in Norway in 2019. When it comes to the oil and gas market, for the maritime industry it contributed $32 \%$, but for shipping companies, the proportion is even higher $-65 \%$ of their revenues come from offshore oil and gas (Hernes et al., 2021).
Considering the interfaces in relationships with several industries, it is important to talk about the development of BM not only from a supply chain perspective. Moreover, it should be considered from the point of view of network value.

This situation can be beneficial from many aspects, but at the same time, it can create many problems as well. The last one can occur due to companies' "willingness" to collaborate: even being advanced in technologies, being part of many common projects, at the same time firms do not want to take risks, have additional costs and fundamental concern about sharing the information - someone can steal ideas and benefit from it. This problem has been an issue for hundred years and it has been named the Arrow information paradox. It is argued that in a free-market economy the lack of protection the property rights can lead to the situation when one firm does not want to share information with buyers because after the disclosure of it potential clients can withdraw to buy it, so the

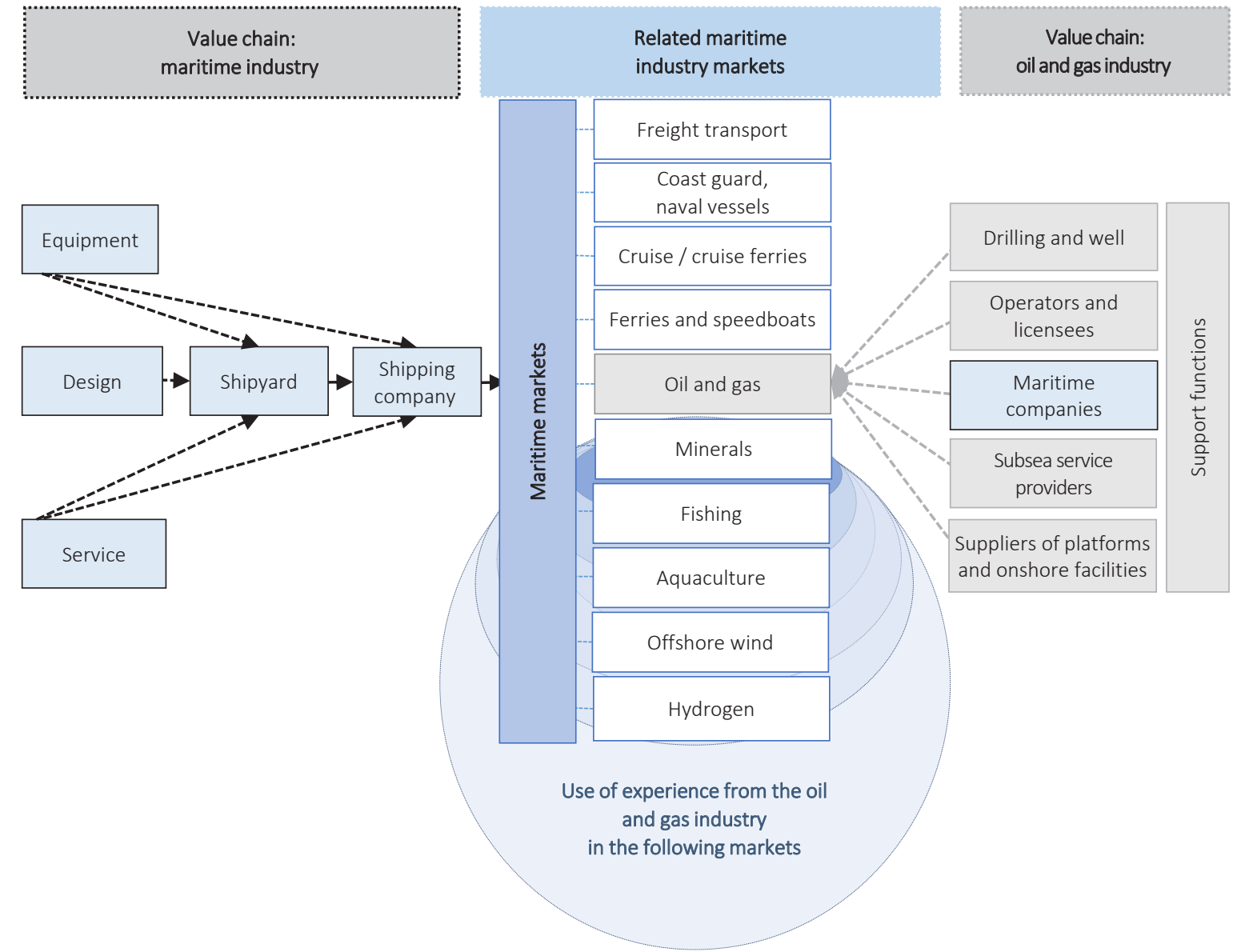

Figure 4. Interfaces in relationships within several industries 
transaction will not happen (Arrow, 1971). Hence, the lack of innovative effort can occur, and everyone will lose from this situation. However, the problem of sharing confidential material, knowledge, or information can be improved by establishing some rules regarding property rights between parties who want to share but want to secure themselves, thus companies can even benefit from the "market for ideas" and innovative efforts can be rewarded (Gans \& Stern, 2003).

Despite the risks, there are more benefits that it gives. The respondents in the survey, conducted by Hernes et al. (2021) believed that experience from the O\&G industry is important for growth in other markets. It is especially in offshore wind and in subsea mining. Hence, the experience from the O\&G industry is important for growth. Norway will be strong in delivering maritime services related to the development of wind farms. Some of the vessels that have previously been used for offshore-related activities can be used for the installation of offshore wind turbines. In the interview round with the companies, it was mentioned that the restructuring has and will lead to somewhat changed competence needs, but that the companies possess much of this competence internally. In addition, shipping companies also believe that the maritime industry succeeds in exporting innovation. Even being a high-cost country, it has not been an obstacle, because Norway has been good at adopting new technology and new solutions. Nevertheless, it has often been the case that companies have developed new products but did not get harvesting as others.

Therefore, it is needed to develop models, calculation tools, and simulator tools that allow testing many solutions and alternatives in a short time. Thus, it is important to start broadly with many possibilities where companies eventually narrow it down until it will be simulated almost 100 percent how it will be in reality. Nevertheless, it is inevitably expensive to pursue technology development. Norwegian companies are always at the forefront of knowledge of new technology. They have also done a lot in the development of competence and tools. Thus, it is important both to evaluate new technology and put together solutions that are best adapted to the customer requirements, as well as be as efficient and environmentally friendly as possible.

\section{FURTHER STUDIES}

Digital transitions in the maritime industry are creating new organizational models, and affect the relationship between ship, ship-owners, and third-party suppliers. New relationships require new business models. Norway aims to be emission-free by 2050 and there are many different current projects where industries and academia collaborate to reach this goal.

One of them is SFI-MOVE project. The idea of it is to optimize operations offshore and established a ship-owner control center in Ålesund. It is believed that autonomous ship technology development will contribute to the competitiveness and sustainability of the maritime industry, in collaboration with other partners.

On the contrary, it is somewhat more difficult to find business models for autonomous ships. The main problem is the maintenance. Today, it is cheaper to have people on board than the investments needed to ensure that technical systems do not need supervision during work. However, more expensive fuel and stronger regulation of emissions can change this. The trend is the same with lower staffing, more automation, as well as new forms of operation and maintenance in modern shipping. In addition, autonomous operation opens up for more flexible transport systems also at sea, in that bigger number and smaller ships can be used. It can provide a better economy plus weight savings that reduce emissions of environmental and greenhouse gases.

Thus, modern business models need to change. Those who are the first out will have the greatest chance of gaining a foothold in the market. SFI MOVE project plans to run experiments, design new solutions, implement, test, and observe the effect of new solutions, as well as develop new BMs.

Hence, the future study aims to design new BMs, test them, and implement the best one, i.e., the goal is to find out how the optimization of marine remote operations can contribute to the development of new BMs.

To achieve this, it is proposed to use the following methodology. First, it is planned to conduct inter- 
views with operators, contractors, and suppliers. Therefore, this can help to develop BMs in terms of network value. Second, it is important to test/evaluate new BMs, so a cost-benefit analysis needs to be done.

\section{CONCLUSION}

In summary, many relevant factors continually drive the development of new BMs and new business relationships in the maritime industry. However, there are still many uncertainties, especially when it comes to a value creation. Partners in the supply chain may have different interests. Some of them may see the potential in the introduction of a new BM in the beginning (reduction of operating expenses (OPEX)), but for many companies, the effect can be seen only in the long run (significant investment - increase of capital expenditures (CAPEX)), so they are not very keen on that.

The literature review pointed out that the BM interprets how an enterprise creates, delivers, and captures value. The concept of a "business model" is usually revealed in nine blocks, structured into four business areas: consumers, functional features and quality of goods and services, specialized infrastructure, and market stability. In addition, there are several archetypes of a BM, the most common are: sustainable business model, business model innovative, and sustainable business model innovative. It was proved that there are several types of BMs, but all of them seek to explain both value creation and holistic approach towards how firms do business.

Developing a BM is a complex process, especially when it comes to a sustainable and innovative business model that aims to make money on new technologies, digitization, and the circular economy. It was found that for this type of model, there is a special tool for starting a business in an innovative way, called "Restart". Besides, there are customer-oriented BM and co-creation BM approaches.

In addition, it was proved that many relevant external and internal factors continually drive the development of new BMs and new business relationships in the maritime industry. In addition to the main world crisis that hit the industry hard, there are also internal factors that just prove the importance of building new competencies and new ways of doing business in the maritime industry.

The results of the study reveal that the development of $\mathrm{BM}$ is a process that requires innovativeness, growing competency, reduction of asymmetry of information, and strengthening the relationship throughout the supply chain. Moreover, considering the interfaces in relationships with several industries, it is vitally important to accept the "logic of network value" rather than focus on a separate value chain. Consequently, this study points to the key reasons for the importance of creating a new BM, and further research is needed.

\section{AUTHOR CONTRIBUTIONS}

Conceptualization: Viktoriia Koilo.

Data curation: Viktoriia Koilo.

Formal analysis: Viktoriia Koilo.

Funding acquisition: Viktoriia Koilo.

Investigation: Viktoriia Koilo.

Methodology: Viktoriia Koilo.

Project administration: Viktoriia Koilo.

Resources: Viktoriia Koilo.

Software: Viktoriia Koilo.

Supervision: Viktoriia Koilo. 
Validation: Viktoriia Koilo.

Visualization: Viktoriia Koilo.

Writing - original draft: Viktoriia Koilo.

Writing - review \& editing: Viktoriia Koilo.

\section{ACKNOWLEDGMENT}

The study is supported by the grant from the Research Based Innovation "SFI Marine Operation in Virtual Environment (SFI-MOVE)" (Project no: 237929) in Norway

\section{REFERENCES}

1. Amit, R., \& Zott, C. (2001). Value Creation in E-Business. Strategic Management Journal, 22(6-7), 493520. http://dx.doi.org/10.1002/ smj.187

2. Amit, R., \& Zott, C. (2008). Exploring the fit between business strategy and business model: Implications for firm performance. Strategic Management Journal, 29(1), 1-26. Retrieved from https://www.semanticscholar.org/ paper/Exploring-the-Fit-BetweenBusiness-Strategy-and-\%3A-* Zott-Amit/7e6090efc9ace72b9e51 1bf876511147b840809f

3. Arrow, K. J. (1971). The Economic Implications of Learning by Doing. In F. H. Hahn (Ed.), Readings in the Theory of Growth. London: Palgrave Macmillan. https://doi. org/10.1007/978-1-349-154302_11

4. Asheim, B. T. (2019). Smart specialisation, innovation policy and regional innovation systems: what about new path development in less innovative regions? Innovation: The European Journal of Social Science Research, 32(1), 8-25. https://doi.org/10.1080/1351 1610.2018.1491001

5. Beattie, V., \& Smith, S. J. (2013). Value Creation and Business Models: Refocusing the Intellectual Capital Debate. British Accounting Review, 45(4), 243-254. https://doi. org/10.1016/j.bar.2013.06.001

6. Berrada, J., Christoforou, Z., \& Leurent, F. (2017). Which Business Models for Autonomous Vehicles? (Conference Paper). ITS EuropeAt. Strasbourg, France. Retrieved from https:// www.researchgate.net/publication/329529327_Which_Business_Models_for_Autonomous_ Vehicles

7. Berre, A. J. (2013). Open business model, process and service innovation with VDML and Service ML (Paper). Proceedings of 5th International IFIP Working Conference on Enterprise Interoperability, 127-142. Retrieved from http:// ceur-ws.org/Vol-1006/paper5.pdf

8. Bocken, N. M. P., Short, S. W., Rana, P., \& Evans, S. (2014). A literature and practice review to develop sustainable business model archetype. Journal of Cleaner Production, 65, 42-56. https://doi. org/10.1016/j.jclepro.2013.11.039.

9. Cabage, N. (n.d.). Business model archetypes: The 7 Fundamental Business Model Personalities. Retrieved from https://nealcabage. com/framework/business-modelarchetypes/

10. Chesbrough, H. (2007). Business model innovation: it's not just about technology anymore. Strategy \& Leadership, 35(6), 12-17. https://doi. org/10.1108/10878570710833714

11. Chew, E. K. (2016). iSIM: An integrated design method for commercializing service innovation. Information Systems Frontiers, 18(3), 457-478. https://doi. org/10.1007/s10796-015-9605-y

12. Dentchev, N., Rauter, R., Jóhannsdóttir, L., Snihur, Y., Rosano, M., Baumgartner, R., Nyberg, T., Tang, X., van Hoof, B., \& Jonker, J. (2018). Embracing the variety of sustainable business models: a prolific field of research and a future research agenda. Journal of Cleaner Production, 194, 695-703. http://doi.org/10.1016/j. jclepro.2018.05.156

13. Ebel, P., Bretschneider, U., \& Leimeister, J. M. (2016). Leveraging virtual business model innovation. Information Systems Journal, 26(5), 519-550. https://doi.org/10.1111/ isj. 12103

14. Equinor (2020). Equinor launching maritime climate ambitions. Retrieved from https://www.equinor. com/en/news/2020-06-08-maritime-climate-ambitions.html

15. European Commission (2014). National/regional innovation strategies for smart specialisation (RIS3). Brussels: European Commission. Retrieved from https://knowledge4policy.ec.europa.eu/publication/ nationalregional-innovation-strategies-smart-specialisation-ris3_en

16. European Commission (2018). Important Projects of Common European Interest. Retrieved from https://ec.europa.eu/commission/ presscorner/detail/en/IP_21_689

17. Foray, D. (2009). Understanding smart specialisation. In D. Pontikakis, D. Kyriakou, \& R. Van Bavel (Eds.), The question of R\&D specialisation, perspectives and policy implications (pp. 14-26). Brussels: Joint Research Center. Retrieved from http://www.eurosfaire.prd. fr/7pc/doc/1253886607_rd_specialisation_jrc51665.pdf

18. Gans, J. S., \& Stern, S. (2003). The Product Market and the Market for "Ideas": Commercialization Strategies for Technology Entre- 
preneurs. Research Policy, 32(2), 333-350. https://doi.org/10.1016/ S0048-7333(02)00103-8

19. Gorgijn, J., Akkermans, H., \& van Vliet, H. (2000). Business Modelling is not Process Modelling. In S. W. Liddle, H. C. Mayr \& B. Thalheim (Eds.), Conceptual Modeling for E-Business and the Web. Springer-Verlag Berlin, Heidelberg. https://doi.org/10.1007/3540-45394-6_5

20. Grillitsch, M., \& Asheim, B. (2018). Place-based innovation policy for industrial diversification in regions. European Planning Studies, 26(8), 1638-1662. https:// doi.org/10.1080/09654313.2018.1 484892

21. Hamel, G. (2000). Leading the Revolution. New York: Plume.

22. Helseth, A. M., Basso, M. N., \& Jakobsen, E. W. (2021). Maritim Verdiskapingsrapport 2021 (Report No. 18/2021). Retrieved from http://s3-eu-west-1.amazonaws.com/maritimt-forum.no/ documents/2021-Maritim-verdiskapingsrapport.pdf

23. Hernes, S., Erraia, J., \& Fjose, S. (2021). Ringvirkninger av olje- og gassnoeringens aktivitet $i 2019$ (Report No. 22/2021). Retrieved from https://www.menon.no/ wp-content/uploads/202122-Ringvirkninger-av-olje-oggassn $\% \mathrm{C} 3 \%$ A6ringens-aktivitet-i-2019.pdf

24. Jacob, E. (2004). Classification and categorization: a difference that makes a difference. Library Trends, 52(3), 515-540. Retrieved from https://www.ideals.illinois.edu/ handle/2142/1686

25. Jakobsen, E. W., \& Helseth, A. M. (2021). Strategier for grønn maritim eksport (Report No. 14/2021). Retrieved from https://www.menon.no/wp-content/uploads/202114-Strategier-for-gr\%C3\%B8nnmaritim-eksport.pdf

26. Jakobsen, E. W., \& Røtnes, R. (2012). Cluster programs in Norway - evaluation of the NCE and Arena programs (Report NR. 1/2012). Retrieved from https:// www.menon.no/wp-content/ uploads/19clusters-programs-indraft-final-report-jan-12-2.pdf
27. Jakobsen, E. W., Helseth, A. M., \& Aamo, A. W. (2020a). GCE Blue Maritime Global Performance Benchmark 2020 (Report No. 107/2020). Retrieved from https:// www.menon.no/publication/ gce-blue-maritime-global-performance-benchmark-2020/

28. Jakobsen, E. W., Stokke, K. E., Hernes, S., Basso, M. N., Helseth, A., \& Erraia, J. (2020b). Omstillingsbehov for Møre og Romsdals eksportnoringer (Report No. 148/2020). Retrieved from https:// www.menon.no/wp-content/ uploads/2020-148-Omstillingsbehov-i-M\%C3\%B8re-og-Romsdalseksportn\%C3\%A6ringer.pdf

29. Jørgensen, S., \& Pedersen, L. J. T. (2017). Restart - 7 veier til borekraftig business (pp.173). Cappelen Damm Akademisk. Retrieved from https://www. adlibris.com/no/bok/restart7-veier-til-barekraftig-business-9788202459192

30. Laukkanen, M., \& Patala, S. (2014). Analysing Barriers to Sustainable Business Model Innovations: Innovation Systems Approach. International Journal of Innovation Management, 18(06), 1-21. https://doi.org/10.1142/ S1363919614400106

31. Magretta, J. (2002). Why Business Models Matter. Harvard Business Review. Retrieved from https:// hbr.org/2002/05/why-businessmodels-matter

32. Malone, T. W., Weill, P., Lai, R., D'Urso, V. T., Herman, G., Apel, T., \& Woerner, S. (2006). Do Some Business Models Perform Better than Others? (MIT Sloan Working Paper No. 4615-06). MIT Center for coordination science working paper. Retrieved from https://mpra.ub.uni-muenchen. de/4752/1/MPRA_paper_4752. pdf

33. Maritimt Forum (2021). Maritim Stortingsmelding: Noeringskomiteen konkretiserer gode ambisjoner. Retrieved from https://www. maritimt-forum.no/sentralt/ nyheter/2021/maritim-stortingsmelding-naeringskomiteenkonkretiserer-gode-ambisjoner

34. OECD. (2012). The Future of Ecoinnovation: The Role of Business
Models in Green Transformation (Paper). OECD/European Commission/Nordic Innovation Joint Workshop. Denmark. Retrieved from https://www.oecd.org/innovation/inno/49537036.pdf

35. Ogilvie, T. (2015). How to thrive in the era of collaborative services entrepreneurship. Research Technology Management, 58(5), 24-33. https://doi. org/10.5437/08956308X5805369

36. Osterwalder, A., \& Pigneur, Y. (2010). Business Model Generation: A Handbook for Visionaries, Game Changers, And Challengers. New York: Wiley.

37. Porter, M., \& Kramer, M. (2011). Creating shared value: How to reinvent capitalism - and unleash a wave of innovation and growth. Harvard Business Review. Retrieved from https:// hbr.org/2011/01/the-big-ideacreating-shared-value

38. Pynnönen, M., Hallikas, J., \& Ritala, P. (2012). Managing customer-driven business model innovation. International Journal of Innovation Management, 16(4), 1-13. https://doi.org/10.1142/ S1363919612003836

39. Rappa, M. (2006). Business Models on the Web. Managing the digital enterprise. The Excutive's Journal, 4, 26-32. Retrieved from http://digitalenterprise.org/models/models.html

40. Regjeringen (2021). Norge mot 2025: Noen utfordringer for en balansert og borekraftig økonomisk utvikling etter pandemien (Report). Retrieved from https://www. norgemot2025.no/utvalget-norgemot-2025-med-andre-delrapport/

41. Schaltegger, S., Lüdeke-Freund, F., \& Hansen, E. (2012). Business cases for sustainability: the role of business model innovation for corporate sustainability. International Journal of Innovation and Sustainable, 6(2), 95-119. http://dx.doi.org/10.1504/ IJISD.2012.046944

42. Smith, J. (n.d.). Lessons from the $C$-suite to help your organization thrive during and after the pandemic. Crowdstrike. Retrieved 
from https://www.crowdstrike. com/resources/crowdcasts/ coping-with-covid-security-leadership-in-times-of-crisis/

43. Solaimani, S., \& Bouwman, H. (2012). A framework for the alignment of business model and business processes. Business Process Management Journal, 18(4), 655-679. https://doi. org/10.1108/14637151211253783

44. Stähler, P. (2002). Business Models as an Unit of Analysis for Strategizing (Paper). Proceedings of the International Workshop on Business Models. Retrieved from http://www. hec.unil.ch/aosterwa/Documents/ workshop/Draft_Staehler.pdf

45. Stubbs, W., \& Cocklin, C. (2008). Conceptualizing a "Sustain- ability business model." Organization \& Environment, 21(2), 103-127. https://doi. org/10.1177/1086026608318042

46. Timmers, P. (1998). Business Models for Electronic Markets. Electronic Markets, 8(2), 3-8. Retrieved from https:// www.tandfonline.com/doi/ abs/10.1080/10196789800000016

47. Trimi, S., \& Berbegal-Mirabent, J. (2012). Business model innovation in entrepreneurship. International Entrepreneurship and Management Journal, 8(4), 449-465. https://doi.org/10.1007/ S11365-012-0234-3

48. Weill, P. D., \& Woerner, S. L. (2018). What's your digital business model? Six questions to help you build the next-generation enterprise. Boston, Massachusetts: Harvard Business Review Press.

49. Zolnowski, A., Weiß, C., \& Böhmann, T. (2014). Representing service business models with the service business model canvas: The case of a mobile payment service in the retail industry. Proceedings of the 47th Hawaii International Conference on System Science (HICSS 2014). Hawaii Big Island. Retrieved from https:// ieeexplore.ieee.org/stamp/stamp. jsp?tp $=\&$ arnumber $=6758692$

50. Zott, C., Amit, R. H., \& Massa, L. (2011). The Business Model: Recent Developments and Future Research. SSRN. http://dx.doi.org/10.2139/ ssrn. 1674384 